\title{
Lietuviška Dèl galvos skausmo prarasto laiko klausimyno versija ir jos patikimumo bei pagristumo vertinimas
}

\section{Zagorskiené*}

E. Abelkis**

R. Mameniškiené*

*Vilniaus universiteto

Neurologijos ir

neurochirurgijos klinika;

Neurologijos centras

**Vilniaus universiteto

Radiologijos, branduolinès

medicinos ir medicinos

fizikos katedra

\begin{abstract}
Santrauka. Ivadas. HALT (angl. Headache-Attributed Lost Time; Dėl galvos skausmo prarastas laikas) klausimynas - tai PSO rekomenduojamas instrumentas, skirtas įvertinti galvos skausmo poveikị kasdienei paciento veiklai. Iki šiol jis nebuvo pritaikytas lietuviškai kalbančiai populiacijai.

Tikslas. Pritaikyti HALT klausimyną lietuviškai kalbančiai populiacijai ir įvertinti jo psichometrines savybes.

Darbo metodika. Atliekant klausimyno kalbinị ir kultūrinį pritaikymą, remtasi Tarptautinès farmakoekonomikos ir išeičių tyrimo draugijos rekomendacijomis. Siekiant ịvertinti klausimyno patikimumą (vidinị nuoseklumą ir stabilumą laiko atžvilgiu), atlikta suaugusių asmenų, besiskundžiančių galvos skausmu, apklausa ir pakartotinė apklausa po 2 savaičių. Vertinant klausimyno konstrukcijos pagrịstumą, naudota vizualinė analoginė skalè (skalè) ir Gyvenimo kokybès SF-36 klausimyno antroji versija.

Rezultatai. Parengta lietuviška HALT klausimyno versija (HALT-LT), atitinkanti kalbinius ir kultūrinius pritaikymo reikalavimus. HALT-LT pritaikyta Lietuvai pagal visus tarptautinius reikalavimus. Nustatytos parengto klausimyno psichometrinès savybės: priimtinas vidinis nuoseklumas ir stabilumas laiko atžvilgiu. Gautos statistiškai reikšmingos koreliacijos visoms suformuluotoms konstrukcijoms.

Išvados. HALT-LT gali būti naudojamas vertinti galvos skausmo ịtaką lietuviškai kalbantiems asmenims. Šis klausimynas gali tapti patogiu įrankiu kasdienėje gydytojo praktikoje, vertinant galvos skausmo sukeliamą naštą.
\end{abstract}

Raktažodžiai: galvos skausmas, dèl galvos skausmo prarastas laikas.

\section{IVADAS}

Galvos skausmas vargina daugiau nei 50 \% europiečių. Jis yra dažniausias aktyvių, dirbančių žmonių populiacijoje. Tipinè įtampos tipo galvos skausmo pradžia - 25-30 metų, migrenos - 2-3 gyvenimo dešimtmetis [1, 2]. Vadinasi, darbingo amžiaus žmonės dažniau neateina ị darbą ar mokymosi įstaigą; sumažèja jų produktyvumas, nukenčia so-

\author{
Adresas: \\ Rüta Mameniškienè \\ Vilniaus universiteto ligoninès Santaros klinikos, \\ Neurologijos centras \\ Santariškiu g. 2, LT-08661 Vilnius \\ El.paštas ruta.mameniskiene@gmail.com
}

cialinè veikla. Tai tampa didele ne tik asmens, bet ir visuomenès problema.

Efektyviam galvos skausmo gydymui svarbu ne tik nustatyti diagnozę, bet ir įvertinti jo sukeliamą naštą. HALT (angl. Headache-Attributed Lost Time; Dèl galvos skausmo prarastas laikas) klausimynas - PSO siūlomas įrankis galvos skausmo sukeliamai naštai ịvertinti [3]. Galvos skausmo sukeliamą naštą, pasitelkiant HALT klausimyną, galima vertinti tiek individualiai, tai yra kasdienèje praktikoje, tiek populiacijos mastu - šis klausimynas dažnai naudojamas epidemiologiniuose tyrimuose [4, 5].

Klausimynas savo struktūra yra labai artimas MIDAS (angl. Migraine Disability Assessment; Migrenos įtaka veiklai) klausimynui, kurị sukūrè ir publikavo W. F. Stewart ir R. B. Lipton, o 2008 m. K. Ryliškienè ir D. Jatužis va-

\footnotetext{
(C) Neurologijos seminarai, 2018. Open Access. This article is distributed under the terms of the Creative Commons Attribution 4.0 International License CC-BY 4.0 (http://creativecommons.org/licenses/by/4.0/), which permits unrestricted use, distribution, and reproduction in any medium, provided you give appropriate credit to the original author(s) and the source, provide a link to the Creative Commons license, and indicate if changes were made.
} 
lidizavo naudoti lietuviškai kalbančiai populiacijai, ir skirtas vertinti migrenos sukeliamai naštai $[6,7]$. Kadangi HALT struktūra yra paprastesnè, jị lengviau išversti ị kitas kalbas, be to, galima naudoti ịvairių galvos skausmo tipų sukeliamai naštai vertinti, nusprendėme pritaikyti ji Lietuvai.

\section{DARBO TIKSLAS}

Pritaikyti HALT klausimyną lietuviškai kalbančiai populiacijai ir îvertinti jo psichometrines savybes: patikimumą ir pagrịstumą.

\section{MEDŽIAGA IR METODAI}

\section{Dèl galvos skausmo prarastas laikas}

HALT sudarytas iš 5 klausimų, apimančių dažniausias suaugusio paciento kasdienès veiklos sritis.

Pildydamas klausimyną, asmuo, kurị vargina galvos skausmas, atsako, kiek dienų per pastaruosius 3 mėnesius jis visai neatvyko ị darbą ar mokymosi ịstaigą dèl galvos skausmų (pirmas klausimas); kiek dienų, atvykęs ị darbą ar mokymosi įstaigą, atliko mažiau nei pusę jam ịprastų darbų ar veiklų (antras klausimas, ị kurị neịtraukiamos dienos, kai pacientas visai nebuvo darbe ar mokymosi įstaigoje). Taip pat prašoma nurodyti, kiek dienų per pastaruosius 3 mėnesius dèl galvos skausmo jis visai neatliko jam ịprastų buities darbų (trečias klausimas); kiek dienų atliko mažiau nei pusę jam įprastų buities darbų (ketvirtas klausimas, ị kurị neịtraukiamos trečiame klausime pasirinktos dienos, kai pacientas visai neatliko jam iprasty buities darbu). Paskutiniame (penktame) klausime, paciento prašoma atsakyti, kiek dienų per pastaruosius 3 mènesius dèl galvos skausmų jis negalejo ịprastai leisti laiko su šeima, nukentėjo jo socialinè veikla ir laisvalaikis.

Galutinis rezultatas gaunamas sudejjus visų penkių klausimų atsakymus. Jei dèl galvos skausmų nukentėjo daugiau nei viena veiklos rūšis, rezultatas gali viršyti dienų, kuriomis vargino galvos skausmas, skaičių. Galutinio rezultato vertinimas: I laipsnis (0-5 dienos) - labai maža įtaka, II laipsnis (6-10 dienų) - maža ịtaka, III laipsnis (11-20 dienų) - vidutinė įtaka, IV laipsnis (>20 dienų) - didelè įtaka kasdienei paciento veiklai.

\section{Pritaikymas Lietuvai}

HALT kalbinis ir kultūrinis pritaikymas atliktas, vadovaujantis Tarptautinès farmakoekonomikos ir išeičių tyrimo draugijos (angl. International Society for Pharmacoeconomics and Outcomes Research, ISPOR) rekomendacijomis [8]. Verčiant ị lietuvių kalbą taip pat remtasi Lifting the burden (LTBT) vertimų grupès rekomendacijomis [9].
Vertimas. Vertimas atliktas gavus skalès kūrèjų leidimą. Vertimo procesą koordinavo gydytojas neurologas (R. M.), laisvai kalbantis lietuvių ir anglų kalbomis.

Klausimyną iš anglų kalbos į lietuvių kalbą išvertė du vertejjai, kurių gimtoji kalba - lietuvių. Vienas iš vertejjų yra susijęs su medicinos sritimi ir supranta HALT reikšmę, kitas - humanitarinị išsilavinimą turintis žmogus, laisvai kalbantis angliškai. Vertejjai dirbo nepriklausomai vienas nuo kito.

Atlikus vertimus, neaiškumai, labiausiai nuo originalo nutolusios vietos buvo aptarti su vertimo koordinatoriumi (R. M). Stebėti smulkūs neatitikimai tarp abiejų vertimų, kurie bendru sutarimu buvo ištaisyti. Sąvoka „namų ruošos darbai“ keista ị „,buities darbai“, „,visuomeniniai ar laisvalaikio renginiai“ - $\mathrm{i}$,,socialinè veikla ir laisvalaikis“. Atsisakyta klausimų konstravimo, naudojant dvi sąlygas. Parengtas bendrai suderintas lietuviškas klausimyno variantas.

Atgalinị suderintos lietuviškos versijos vertimą i anglų kalbą atliko du vertėjai, kurie neturi medicininio išsilavinimo ir laisvai kalba angliškai bei lietuviškai. Vertẻjai dirbo nepriklausomai vienas nuo kito. Atlikus atgalinius vertimus, jie palyginti su originalu. Kilę smulkūs neatitikimai (pvz., „household work“ ir „household chores“) aptarti su vertimo koordinatoriumi (R. M.). Parengta pradinė lietuviška HALT versija.

Pradinis klausimyno ịvertinimas ir galutinès versijos sukūrimas. Pradiniam klausimyno ịvertinimui atrinkta 10 ịvairaus amžiaus ir išsilavinimo respondentų, besiskundžiančių galvos skausmu. Jų buvo prašoma atsakyti ị HALT klausimus, garsiai komentuojant, nurodant neaiškumus. Atsižvelgus į respondentų pastabas, buvo parengta galutinè lietuviška HALT klausimyno versija, atitinkanti kalbinius ir kultūrinius pritaikymo reikalavimus.

\section{HALT-LT psichometrinių savybių vertinimas}

Prospektyvinis tyrimas atliktas 2017 m. kovo-balandžio mėnesiais. Atlikta internetinė pacientų apklausa, kurią sudarẻ klausimai apie respondentų demografinius duomenis (lytị, amžių, užsièmimą), klausimai apie patiriamą galvos skausmą (galvos skausmo stiprumas pagal vizualinę analoginę skalę, ar per pastaruosius 3 mèn. vargino galvos skausmas), HALT-LT klausimynas ir lietuviškas Gyvenimo kokybės klausimynas SF-36v2. Naudotis pastaruoju klausimynu gautas Quality Metric Incorporated kompanijos leidimas.

Atlikus internetinę pacientų apklausą, gauti 226 respondentų atsakymai. I tyrimą buvo ịtraukti 133 respondentai, per pastaruosius 3 mènesius besiskundžiantys galvos skausmu, kurie pilnai ir savarankiškai užpildè visas apklausos dalis. Visų pacientų iš anksto buvo pasiteirauta, ar jie sutiktų klausimyną užpildyti dar kartą. 82 respondentai sutiko pakartotinai atsakyti ic apklausos klausimus po dviejų savaičių (1 lentelè). Kiekvienas tiriamasis buvo raštu informuotas apie tyrimo tikslus, tyrimo duomenų panaudojimą ir konfidencialumą. Gautas kiekvieno 


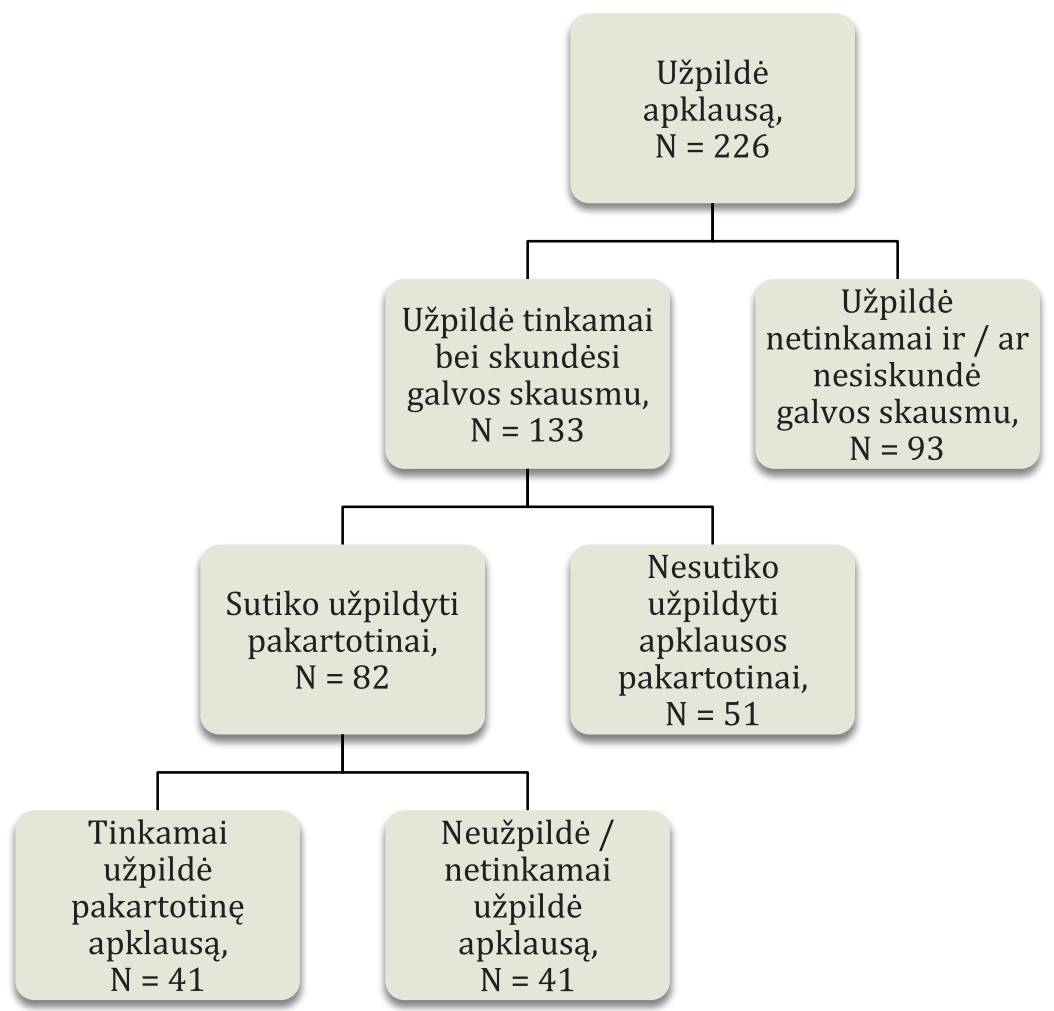

1 pav. Apklausos pildymas ir tiriamujų įtraukimas/neįtraukimas ị tyrimą bės klausimyno SF-36v2 rezultatai apdoroti, naudojant programinę ịrangą QualityMetric Health Outcomes ${ }^{T M}$ Scoring Software.

Klausimyno vidinis nuoseklumas. Vertinant HALT-LT klausimyno vidini nuoseklumą, nustatyta, kaip stipriai tarpusavyje koreliuoja tiek pirmos, tiek pakartotinės apklausos metu gautų atsakymų įverčiai. Skalès patikimumui nustatyti apskaičiuotas Cronbach $\alpha$ koeficientas, rodantis visų skalès klausimu tarpusavio ryšic. Laikyta, kad skalè labai patikima, kai $\alpha>0,8$; pakankamai patikima, kai $\alpha>0,7$ [10].

Stabilumas laiko atžvilgiu nustatytas, apskaičiuojant vidinị klasės koreliacijos koeficientą (VKK). Naudotasi VKK dviejų faktorių mišriu modeliu (angl. Two-way mixed model). Laikyta, kad, jei VKK ivertis yra daugiau nei 0,75 , patikimumas priimtinas [11].

Klausimyno konstrukcijos pagrịstumas. Vertinant klausimyno konstrukcijos pagrịstumą, pagal vizualinès analoginès skalès ir gyvenimo kokybès klausimyno SF-36v2 duomenis suforrespondento informuoto asmens sutikimas dalyvauti tyrime.

Po dviejų savaičių susisiekta su 82 pacientais, sutikusiais atsakyti ic anketos klausimus pakartotinai. Laikyta, kad dvi savaitės yra pakankamas laiko tarpas, kad pacientai neprisimintų savo atsakymų, ir kartu ne per ilgas, kad esminiai duomenys apie patiriamą ar patirtą galvos skausmą pasikeistų. Pakartotinès apklausos metu gauti 61 tiriamojo atsakymai. I tyrimą įtraukta 41 respondentas, kuris pakartotinai iki galo atsakè ic visus HALT klausimyno klausimus (1 lentelè). Neįtraukti respondentai, kurie netiksliai ar nesuprantamai nurodè galvos skausmo paveiktu dienų skaičių (1 pav.).

Statistiniai skaičiavimai atlikti naudojant IBM SPSS 23.0 programinès įrangos versiją. Gyvenimo koky- muluotos 5 konstrukcijos:

1) asmenys, kurie per pastaruosius 3 mèn. patyrè stipresnị galvos skausmą pagal VAS, turi didesnị bendrą HALT-LT įverti;

2) asmenys, kurie dažniau susidūrè su sunkumais darbe ar kitoje ịprastoje kasdienèje veikloje dèl fizinès sveikatos problemų (pagal SF-36v2), turi didesnị bendrą HALT-LT ivertic;

3) asmenys, kurie dažniau susidūrè su sunkumais darbe ar kitoje ịprastoje kasdienėje veikloje dẻl emocinès sveikatos problemų (pagal SF-36v2), turi didesnị bendrą HALT-LT ịvertic;

4) asmenys, kurių fizinès sveikatos ar emocinės problemos labiau trukdè normaliai visuomeninei veiklai (pagal SF-36v2), turi didesnị bendrą HALT-LT ịvertį;

1 lentelè. Respondentų demografiniai duomenys, skausmo intensyvumas pagal vizualinę analoginę skalę (VAS) ir HALT suma

\begin{tabular}{||l|c|c||}
\hline \hline & Pirma apklausa & Pakartotinė apklausa \\
\hline Tiriamujų skaičius & 133 & 41 \\
\hline Lytis: mot./vyr., \% & $121 / 12(91 / 9)$ & $39 / 2(95,1 / 4,9)$ \\
\hline Amžius (metai), vidurkis \pm standartinis nuokrypis & $29,7 \pm 8,9$ & $30,7 \pm 9,9$ \\
\hline Gyv. vieta: miestas, kaimas, \% & $122 / 11(91,7 / 8,3)$ & $37 / 4(90,2 / 9,8)$ \\
\hline Užsiėmimas: & & $22(53,7)$ \\
dirba, \% & $66(49,6)$ & $9(22,0)$ \\
studijuoja/mokosi, \% & $37(27,8)$ & $8(19,5)$ \\
dirba ir studijuoja/mokosi, \% & $24(18,0)$ & $2(4,8)$ \\
kita (vaiko auginimo atostogos, bedarbis), \% & $6(4,5)$ & $6,6 \pm 1,7$ \\
\hline Skausmas pagal VAS & $6,8 \pm 1,8$ & $16,42 \pm 32,6$ \\
\hline HALT suma & $12,6 \pm 21,5$ & \\
\hline
\end{tabular}


HALT klausimynas (dèl galvos skausmo prarastas laikas)

\begin{tabular}{|c|}
\hline 1. Kiek dienų per pastaruosius tris mėnesius dėl galvos skausmų Jūs neatvykote ị darbą ar mokymosi įstaigą? \\
\hline $\begin{array}{l}\text { 2. Kiek dienų per pastaruosius tris mėnesius dėl galvos skausmų Jūs atlikote mažiau nei pusę Jums ịprastų veiklų darbe } \\
\text { ar mokymosi įstaigoje? (Neįtraukite } 1 \text { klausimo dienų, kai visai neatėjote ị darbą ar mokymosi įstaigą.) }\end{array}$ \\
\hline 3. Kiek dienų per pastaruosius tris mėnesius dèl galvos skausmų Jūs visai neatlikote Jums ịprastų buities darbų? \\
\hline $\begin{array}{l}\text { 4. Kiek dienų per pastaruosius tris mėnesius dėl galvos skausmų Jūs atlikote mažiau nei pusę Jums ịprastų buities darbų? } \\
\text { (Neįtraukite } 3 \text { klausimo dienų, kai visai neatlikote buities darbų.) }\end{array}$ \\
\hline $\begin{array}{l}\text { 5. Kiek dienų per pastaruosius tris mėnesius dèl galvos skausmų negalėjote leisti laiko su šeima, nukentėjo Jūsų socialinė } \\
\text { veikla ir laisvalaikis? }\end{array}$ \\
\hline
\end{tabular}

\section{Vertinimas}

\begin{tabular}{||c|c|c||}
\hline HALT ịvertis & İtaka kasdienei veiklai & Laipsnis \\
\hline $0-5$ & Labai maža & I laipsnis \\
\hline $6-10$ & Maža & II laipsnis \\
\hline $11-20$ & Vidutine & III laipsnis \\
\hline $20+$ & Didelè & IV laipsnis \\
\hline
\end{tabular}

2 pav. HALT klausimynas ir jo vertinimas

5) asmenys, patyrę stipresnị kūno skausmą, kuris labiau trukdè normaliam darbui (pagal SF-36v2), turi didesnị bendrą HALT-LT įvertị.

Konstrukciju pagristumas ivertintas, naudojant Spearman's rho koreliacijos testą (patikima, kai $\mathrm{p}<0,05$ ). Kuo HALT ivertis didesnis, tuo labiau sutrikusi kasdienè asmens veikla. Ir priešingai - kuo didesnis SF-36v2 įvertis, tuo mažiau problemų patiria asmuo. Todèl tikètasi gauti neigiamas (atvirkštines) koreliacijas 2-5 konstrukcijoms.

2 lentelè. Vidinio klasės koreliacijos koeficiento įverčiai tarp pirmos ir pakartotinès apklausos atsakymu

\begin{tabular}{||l|c|c|c||}
\hline & $\begin{array}{c}\text { Pirma apklausa } \\
(\mathbf{N}=\mathbf{1 3 3}), \mathbf{M} \pm \mathbf{S N}\end{array}$ & $\begin{array}{c}\text { Pakartotine apklausa } \\
(\mathbf{N}=\mathbf{4 1}), \mathbf{M} \pm \mathbf{S N}\end{array}$ & $\begin{array}{c}\text { Vidinis klasės kore- } \\
\text { liacijos koeficientas }\end{array}$ \\
\hline HALT 1 klausimas & $0,5 \pm 3,1$ & $0,9 \pm 5,1$ & 0,938 \\
\hline HALT 2 klausimas & $3,1 \pm 4,4$ & $4,7 \pm 7,2$ & 0,805 \\
\hline HALT 3 klausimas & $2,3 \pm 4,1$ & $2,5 \pm 5,3$ & 0,913 \\
\hline HALT 4 klausimas & $3,6 \pm 5,3$ & $3,7 \pm 6,5$ & 0,899 \\
\hline HALT 5 klausimas & $4,6 \pm 9,5$ & $4,9 \pm 9,7$ & 0,979 \\
\hline HALT suma & $14,6 \pm 24,7$ & $17,2 \pm 32,6$ & 0,966 \\
\hline
\end{tabular}

$\mathrm{M}$ - vidurkis, $\mathrm{SN}$ - standartinis nuokrypis.

3 lentelè. Koreliacijos tarp HALT sumos ir SF-36v2 klausimyno vertintų sferų, visais atvejais $\mathbf{p}<\mathbf{0 , 0 1}$

\begin{tabular}{||l|c||}
\hline SF-36v2 sfera & $\begin{array}{c}\text { Spearman's rho kore- } \\
\text { liacijos koeficientas }\end{array}$ \\
\hline Fizinis funkcionalumas & $-0,274$ \\
\hline Veiklos apribojimas dėl fizinės sveikatos problemų & $-0,543$ \\
\hline Fizinis skausmas & $-0,467$ \\
\hline Bendra sveikatos būklė & $-0,234$ \\
\hline Gyvybingumas & $-0,381$ \\
\hline Socialinės / visuomeninės funkcijos & $-0,511$ \\
\hline Veiklos apribojimas dèl emocinių problemų & $-0,283$ \\
\hline Psichinė būklè & $-0,313$ \\
\hline
\end{tabular}

\section{REZULTATAI}

Lietuviška HALT versija pritaikyta Lietuvai pagal visus tarptautinius reikalavimus (2 pav.).

Klausimyno vidinis nuoseklumas. Apklausos metu nustatyta priimtina Cronbach $\alpha$ reikšmė 0,824 , rodanti aukštą klausimyno vidinị nuoseklumą.

Stabilumas laiko atžvilgiu. Ivertintas stabilumas laiko atžvilgiu po 2 savaičių pakartotinio testavimo metodu. Apskaičiuotas vidinis klasės koreliacijos koeficientas kiekvienam HALT-LT klausimui, visais atvejais VKK > 0,8 (2 lentelè). Pirminès ir pakartotinės apklausos metu gautų atsakymų i kiekvieną HALT-LT klausimą ịverčiai laiko atžvilgiu reikšmingai nesiskyrè.

Klausimyno konstrukcijos pagrịstumas. Gautos statistiškai reikšmingos koreliacijos visoms suformuluotoms konstrukcijoms pagal VAS ir SF-36v2 rezultatus. 1 konstrukcijai tarp VAS ir HALT sumos - Spearman's rho lygu 0,382, p < 0,01. Likusioms 2-5 konstrukcijoms tarp SF-36v2 veiklos sričių ir HALT-LT galutinio rezultato taip pat gautos statistiškai reikšmingos neigiamos koreliacijos, $\mathrm{p}<0,01$. HALT-LT galutinis rezultatas geriausiai koreliavo su veiklos apribojimu dèl fizinės sveikatos problemų ir socialinių (visuomeninių) funkcijų sfera (3 lentelè). 


\section{REZULTATU APTARIMAS}

Atlikus literatūros apžvalgą, aišku, kad iki šiol trūksta instrumentų lietuvių kalba, padedančių ìvertinti galvos skausmo įtaką kasdienei paciento veiklai. Prieš dešimtmeti ị lietuvių kalbą buvo išverstas ir migrena sergančiųjų grupei pritaikytas MIDAS-LT klausimynas, skirtas migrenos sukeliamai naštai vertinti [7]. Tačiau trūko instrumentų, galinčių padėti nustatyti galvos skausmo naštą, nepriklausomai nuo galvos skausmo tipo. Naujo instrumento sukūrimas palyginti nedidelei Lietuvos populiacijai galimai reikalautų didelių tiek ekonominių, tiek laiko sąnaudų. Pasirinkta ị lietuvių kalbą išversti jau parengtą HALT klausimyną, kurị rekomenduoja ir PSO, ir ịvertinti jo psichometrines savybes.

2010 m. Colette Andrée su bendraautoriais sukūrè EUROLIGHT klausimyną, vertinanti pirminių galvos skausmų naštą. Viena iš klausimyno dalių buvo ir HALT indeksas [12]. Klausimynas buvo išverstas ị 5 kalbas (anglų, italų, ispanų, vokiečių ir prancūzų), įvertintos psichometrinès savybès.

Šioje studijoje dalyvavo 133 respondentai, $91 \%$ jų buvo moterys. Tai galima paaiškinti tuo, kad moterys nuo galvos skausmų kenčia dažniau, taip pat dèl galvos skausmų dažniau kreipiasi pagalbos [2]. Respondentų amžiaus vidurkis - 29,7 $\pm 8,9$ m. Didžioji dalis respondentų - dirbantys asmenys (49,6 \%), mažesnè dalis studijavo ar mokèsi $(27,8 \%), 18 \%$ - ir dirbo, ir studijavo. Tik nedidelè dalis $-4,5 \%$ respondentų - nedirbo ir nestudijavo ar nesimokè. Vidutinis HALT-LT įvertis per pastaruosius 3 mėnesius - 12,6 \pm 21,5 dienos; tai atitinka III laipsnio, arba vidutinę, ịtaką kasdienei veiklai. Mažiausiai dienų praleista, neateinant ị darbą ar mokymosi įstaigą $(0,5 \pm 3,1$ dienos); labiausiai nukentejjo laikas su šeima, socialinès veiklos ir laisvalaikis (4,6 \pm 9,5 dienos). Validizuojant EUROLIGHT klausimyną, respondentų skaičius svyravo nuo 45 iki 131, priklausomai nuo šalies. Dauguma respondentų visose šalyse taip pat buvo moterys. Respondentų amžius svyravo nuo 38,18 \pm 11,67 iki $50,14 \pm 11,75 \mathrm{~m}$. Dauguma respondentų taip pat buvo dirbantys, tačiau išskirta, kad dalis respondentų jau buvo pensininkai [12].

Šioje studijoje gautas Cronbach $\alpha$ ịvertis, lygus 0,824, tai rodo aukštą klausimyno vidini nuoseklumą. EUROLIGHT projekte atsakymų i HALT klausimus Cronbach $\alpha$ ịvertis svyravo nuo $0,69 \mathrm{iki}$ 0,91 ir yra palyginamas su šios studijos rezultatu [12].

EUROLIGHT projekte pakartotinai iki galo klausimyną užpildẻ nuo 63 iki $100 \%$ respondentų, priklausomai nuo šalies. Laiko periodas tarp pirmos ir pakartotinès apklausos buvo 1 mėnuo. Vidinis klasės koreliacijos koeficientas tarp pirmą ir antrą kartą atsakytų HALT klausimų: Jungtinėje Karalystėje svyravo nuo 0,83 iki 0,92, Italijoje - 0,60-0,97, Ispanijoje - 0,88-0,95, Vokietijoje ir Austrijoje - 0,55-0,94, Prancūzijoje $0,58-0,94$. Šiame tyrime pakartotinai anketa buvo pildoma po 2 savaičių, ją užpildè mažiau respondentų -
$30,8 \%$ (arba 41 iš 133 respondentų). Tačiau VKK buvo aukštesnis nei patenkinamas ir svyravo nuo 0,80 iki 0,97 .

Konstrukcijų pagrịstumas šioje studijoje vertintas, nustatant sąsajas tarp HALT-LT įverčio ir VAS bei SF-36v2 rezultatų. Validizuojant lietuvišką MIDAS versiją, taip pat buvo naudojamasi SF-36v2 klausimynu [7]. Tarp HALT-LT ir VAS gauta silpna koreliacija, tačiau ji - statistiškai patikima. Tarp HALT-LT galutinio ịverčio ir tokių SF-36v2 sferų kaip veiklos apribojimas dèl fizinès sveikatos problemų, fizinis skausmas ir socialinès ar visuomeninès funkcijos gautos vidutinio stiprumo koreliacijos. Koreliacijos su kitais SF-36v2 domenais buvo silpnos, bet visais atvejais statistiškai patikimos. EUROLIGHT projekte konstrukcijų pagrịstumas vertintas, lyginant HALT indekso, PSO gyvenimo kokybès klausimyno (WHO QoL) ir ligoninès nerimo ir depresijos skalès (HADS) įverčius [12]. Todèl rezultatai negali būti palyginti.

Didžiausias šios studijos privalumas - HALT-LT indekso vertimas ir psichometrinių savybių patikrinimas atliktas, vadovaujantis tiek ISPOR, tiek LTBT rekomendacijomis. Pagrindiniai trūkumai: tyrime nebuvo analizuota, kokiu galvos skausmo tipu ir kaip dažnai kiekvienas respondentas skundžiasi. Taip pat nebuvo surinkta duomenų apie skausmo gydymą, o tai galejjo daryti ịtaką rezultatams.

\section{IŠVADOS}

HALT-LT klausimynas pritaikytas lietuviškai kalbančiai populiacijai. Šis instrumentas gali tapti patogiu įrankiu kasdienėje gydytojo praktikoje, ịvertinant paciento galvos skausmo sukeliamą naštą ir priimant sprendimą dèl gydymo intensyvumo.

\section{Literatūra}

1. Jensen R, Stovner L. Epidemiology and comorbidity of headache. Lancet Neurol 2008; 7(4): 354-61. https://doi.org/ 10.1016/S1474-4422(08)70062-0

2. Stovner LJ, Andree C. Prevalence of headache in Europe: a review for the Eurolight project. J Headache Pain 2010; 11(4): 289-99. https://doi.org/10.1007/s10194-010-0217-0

3. Steiner TJ. Lifting the burden: the global campaign to reduce the burden of headache worldwide. J Headache Pain 2005; 6: 373-7. https://doi.org/10.1007/s10194-005-0241-7

4. Steiner TJ, Lipton RB, Lifting The Burden: The Global Campaign against Headache. The Headache-Attributed Lost Time (HALT) Indices: measures of burden for clinical management and population-based research. J Headache Pain 2018; 19(1): 12. https://doi.org/10.1186/s10194-018-0837-3

5. Steiner TJ, Stovner LJ, Katsarava Z, Lainez JM, Lampl C, Lantéri-Minet M, et al. The impact of headache in Europe: principal results of the Eurolight project. J Headache Pain 2014; 15: 31. https://doi.org/10.1186/1129-2377-15-31

6. Stewart WF, Lipton RB, Whyte J, Dowson A, Kolodner K, Liberman JN, et al. An international study to assess reliability 
of the Migraine Disability Assessment (MIDAS) score. Neurology 1999; 53(5): 988-94. https://doi.org/10.1212/ WNL.53.5.988

7. Ryliškienė K, Jatužis D. Lietuviška migrenos ịtakos veiklai klausimyno versija ir jos patikimumo bei pagrịstumo įvertinimas. Neurol Semin 2008; 12(36): 82-7.

8. Eddy DM, Hollingworth W, Caro JJ, Tsevat J, McDonald KM, Wong JB, et al. Model transparency and validation: a report of the ISPOR-SMDM Modeling Good Research Practices Task Force-7. Medical Decision Making 2012; 32(5): 733-43. https://doi.org/10.1177/ 0272989X12454579

9. Linguistic Translation - Lifting The Burden. Web Site [Internet]. [Accessed 2018 Feb 11]. Available at: http://www.1-t-b.org/index.cfm/spKey/horizontal_ activities.supporting.linguistic_translation.html

10. Streiner D. Starting at the beginning: an introduction to coefficient alpha and internal consistency. J Pers Assess 2003; 80: 99-103. https://doi.org/10.1207/S15327752JPA8001_18

11. Koo TK, Li MY. A guideline of selecting and reporting intraclass correlation coefficients for reliability research. J Chiropr Med 2016; 15(2): 155-63. https://doi.org/10.1016/ j.jcm.2016.02.012

12. Andrée C, Vaillant M, Barre J, Katsarava Z, Lainez JM, Lair M-L, et al. Development and validation of the EUROLIGHT questionnaire to evaluate the burden of primary headache disorders in Europe. Cephalalgia Int J Headache 2010; 30(9): 1082-100. https://doi.org/10.1177/ 0333102409354323

\section{Zagorskienė, E. Abelkis, R. Mameniškienè}

\section{RELIABILITY AND VALIDITY OF THE LITHUANIAN VERSION OF HEADACHE-ATTRIBUTED LOST TIME (HALT) INDEX}

\section{Summary}

Background. Headache-Attributed Lost Time (HALT) index is a tool recommended by WHO to determine the burden of headache to the patient and his everyday life. This instrument has not been validated in Lithuanian so far.

Objective. To perform cross-cultural adaptation of the Lithuanian HALT version and to test its reliability and validity.

Materials and methods. The questionnaire was culturally adapted for Lithuanian speaking population following the recommendations of International Society for Pharmacoeconomics and Outcomes Research. Psychometric properties of HALT were tested on adults complaining of headache of any kind. Internal consistency and test-retest reliability after 2 weeks were determined. Construct validity was assessed using Visual Analog Scale (VAS) for Pain and Lithuanian version of SF-36v2 questionnaire.

Results. Lithuanian version of HALT index (HALT-LT) satisfying requirements of linguistic and cultural adaptation was prepared. HALT-LT demonstrated acceptable internal consistency and test-retest reliability. Correlations for all proposed constructs were significant.

Conclusions. HALT-LT can be used as an instrument for adult patients in Lithuanian speaking population. This questionnaire can become a convenient tool in the daily practice of a physician, assessing the burden of a headache.

Keywords: headache, cross-cultural adaptation, reliability, validity.

Gauta:

20180114

Priimta spaudai: 20180208 